\title{
Cerebral Pathology in Immunodeficient Gnotobiotic Laboratory Mice
}

\author{
Piotr SURA and Zbigniew SREBRO
}

Accepted September 6, 2005

\begin{abstract}
SURA P., SREBRo Z. 2005. Cerebral pathology in immunodeficient gnotobiotic laboratory mice. Folia biol. (Kraków) 53: 205-208.

Gnotobiotic autoimmunity prone, antigen presentation, $\mathrm{T}$ lymphocyte receptor gene knockout mice show cerebral pathology in the form of meningitis, venous blood statis with subarachnoid hemorrhages and massive hemosiderin deposits. A more or less severe hydrocephalus was present in all animals examined. In all cases except the $\mathrm{CD}^{-/-}$animals, the pineal gland was considerably reduced in mass. Only in the latter strain was a strong pineal hypertrophy in the form of a benign tumor present in ca. $50 \%$ of the animals. A possible sequence of events leading to hydrocephalus is discussed. Endogenous vertically transmitted facultative pathogens, active in the immunocompromised animals, probably play a primary etiological role. The results show that caution is needed in planning immunobiological studies on the B10.PL and B10.PL-derived mice, and possibly other strains not examined for possible neuropathological changes.
\end{abstract}

Key words: Knockout mice brain, hydrocephalus, meningitis, hemosiderin.

Piotr SURA, Zbigniew SREBRO, Department of Human Developmental Biology, Collegium Medicum, Jagiellonian University, Kopernika 7, 31-034 Kraków, Poland.

E-mail:mbsura@cyf-kr.edu.pl

Gnotobiotic immunologically-active molecule mutant or knockout mice are commonly used in studies on immunological mechanisms and animal models of human autoimmune diseases (e.g., SABELKO-DOWNES et al. 2000; MACPHERSON et al. 2001; PAUL et al. 2003; SZCZEPANIK et al. 2003). In the course of a routine histological examination of the cerebra of pathogen-free autoimmunity prone and immunological molecule knockout mice, moderate to severe pathological changes in their cerebra were observed. Meningitis and hydrocephalus of various grade were the most spectacular changes. In this report a description is given of pathomorphologic features of the intracranial blood vessels, the meninges and gross and histological structure of cerebra of these animals. The cause(s) and pathomorphologic process(es) leading to the hydrocephalus in the B10.PL and B10.PL-derived knockout mice are analyzed.

\section{Material and Methods}

Pathogen-free young adult mice 3 months old of both sexes bred and housed in the Department of
Human Developmental Biology under the care of Dr. M. Szczepanik were used. The $\mathrm{CD}^{-/-}$, TCR $\delta^{-/-}$, TCR $\alpha^{-/-}$, and $\beta 2 \mathrm{~m}^{-/-}$knockout mice* derived from the B10.PL strain were originally obtained from professor C. A. JANEWAY, Jr., Yale University School of Medicine. The B10.PL strain that requires the activation of autoreactive $\mathrm{T}$ cells for the expression of pathology was purchased from The Jackson Laboratory (Bar Harbor, Maine). Forty adult Swiss and BALB/c mice of same age and sex kept under standard laboratory conditions served for a comparison. Brains of 28 immunodeficient animals were histologically examined in detail. Immediately after killing, the cranium was quickly opened and the brain was immediately fixed in situ with Bouin's fluid. Perfusion fixation appeared unsuitable because of the presence of blood clots in the brain vessels. After removal, the cerebra were dehydrated in a graded series of ethanol, embedded in paraffin and cut at $7 \mu \mathrm{m}$. The deparaffinized sections were stained with the chrome hematoxylin-phloxin method of Gomori (PEARSE 1960) or the Giemsa stain.

\footnotetext{
*The knockout mice are homozygotic for the lack of both normal genes coding for the CD1 antigen, the T cell receptor $\delta$ chain, the T cell receptor $\alpha$ chain, and the $\beta 2$ microglobulin, respectively.
} 

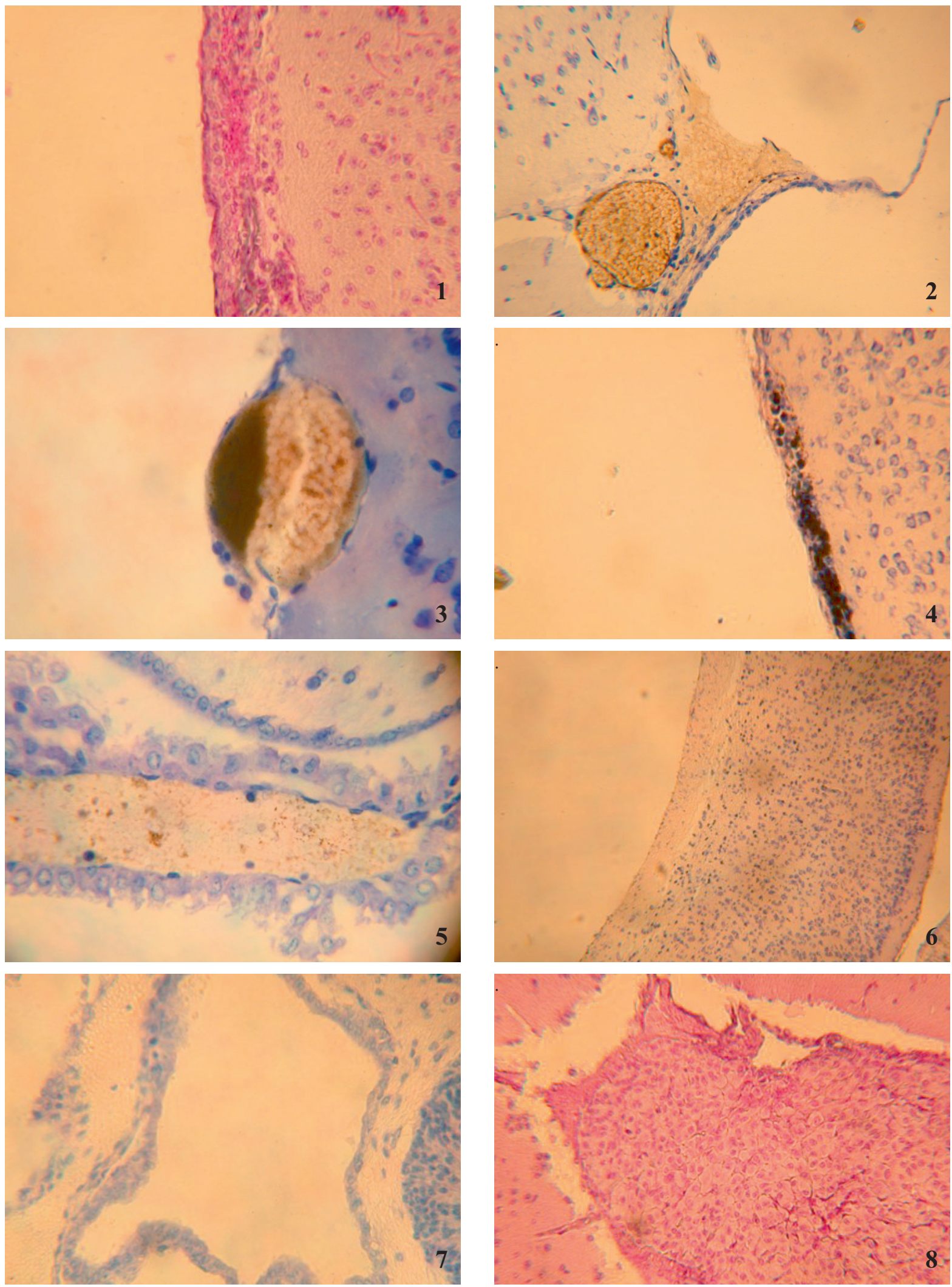

Figs 1-8. Fig. 1. Meningitis in a B10.PL mouse. The pia is thickened by infiltration of inflammatory cells and hyperemia. Chrome hematoxylin-phloxin, $\times 200$. Fig. 2. Fragment of meninges in a TCR $\delta^{-1-}$ mouse. Note the extremely dilated subarachnoid space and a dilated superficial vein with hemosiderin deposits. A hemorrhage is observed in the subarachnoid space. Giemsa stain, $\times 200$. Fig. 3. Meningeal vein at higher magnification in a $\beta 2 \mathrm{~m}^{-/}$animal. Part of the vessel is filled with a homogenous mass of hemosiderin. Giemsa stain, $\times 400$. Fig. 4 . Hemosiderin and lipofuscin deposits in the meningeas and meningeal vessels in a $\beta 2 \mathrm{~m}^{-1}$ animal. Giemsa stain, $\times 200$. Fig. 5 . Strongly dilated vein of choroid plexus III with small and medium-sized hemosiderin deposits in a TCR $\delta^{--}$mouse, $\times 400$. Fig. 6. Cerebral hemisphere in a case of severe hydrocephalus in a $\beta 2 \mathrm{~m}^{--}$mouse. Note the disappearance and shrinkage of neurons and gliosis. Giemsa stain, $\times 160$. Fig. 7. Strongly distended lumen of the III brain ventricle with reduction of the glandular tissue of the pineal gland in a BI0.PL mouse. Giemsa stain, $\times 200$. Fig. 8. Pineal tumor in a $\mathrm{CD}^{-1}$ mouse. Chrome hematoxylin-phloxin, $\times 200$. 


\section{Results}

An almost universal finding was a localized thickening and fibrosis of the pia (Fig. 1). In all cases the large superficial veins were extremely dilated and filled with blood clots and subarachnoid hemorrhages were a common finding (Fig. 2). In the clots and the hemorrhages massive hemosiderin deposits were abundant as finely granular or large masses (Figs 2-4). Frequently, the large veins draining deeper parts of the brain and lying at the base of the choroid plexus of the third ventricle were distended and filled with a thrombus with hemosiderin deposits (Fig. 5).

Another universal finding was an internal and external hydrocephalus of varying severity. In the most severe case of a $\beta 2 \mathrm{~m}^{-/-}$knockout mouse the brain was destroyed in its deeper subcortical parts, only a narrow remainder of the cerebral hemispheres remaining (Fig. 6). The elevated pressure of the cerebrospinal fluid in the dilated cerebral ventricles and the subarachnoid space caused considerable destruction of the brain parenchyma with loss of neurons and gliosis (Fig. 6). The dilated hydrocephalic ventricles had hemosiderin and macrophages in the extravasated blood. The pineal gland was strongly distended, lacking glandular tissue (Fig. 7). In two $\mathrm{CD}^{-/-}$knockout mice, however, a considerable hypertrophy of the pineal gland was present in the form of a benign tumor (Fig. 8). The animal with the most severe hydrocephalus was moribund and was therefore sacrificed in a state of severe emaciation. No clear differences in brain pathology between the different types of knockout animals were observed, except the above mentioned pineal tumors. No elevated mast cell numbers were found neither near large pial blood vessels nor in the brain parenchyma at the microvessels. However, mast cell infiltration of the dura was a frequent finding. The BALB/c comparison mice, on the contrary, always have mast cells near or at large pial and brain parenchyma microvessels in the epithalamus and thalamus, sometimes in considerable numbers. None of the cerebral pathologies found in the autoimmunity-prone and knockout animals was observed in Swiss and BALB/c strains except sporadic, ca. $10 \%$, considerable pineal hypertrophy in the BALB/c animals.

\section{Discussion}

The sequence of pathogenetic events leading to the hydrocephalus probably is the following: meningeal fibrosis causes constriction of the thinwalled large veins draining the brain and the blood stasis and clots impair the outflow of blood from the intracranial space. As a consequence the clear- ance of the cerebrospinal fluid is impaired leading to the formation of hydrocephalus. However, hydrocephalus in our animals may also be inborn; the B10.PL mice are derived from the C57BL/6J strain (JAX®Mice Database - B6.B10(PL)) that possess a characteristic, hereditary hydrocephalus and it can be assumed that the B10.PL mice developed the hydrocephalus spontaneously. Spontaneous hydrocephalus occurs in a number of laboratory strains, but its frequency never exceeds 1\% (SUNDBERG et al. 1991). Apparently no such data exists as regards the B10.PL, the B10.PLderived knockouts, or the $\mathrm{BALB} / \mathrm{c}$ strain.

The cause of the meningitis and blood stasis with hemorrhages can only be guessed at the moment. The autoimmunity-prone and knockout mice certainly have their immunological defenses impaired. They should have no bacterial or viral infections since they were reared in sterile conditions. However, there are strong indications that mice in general harbor endogenous facultative bacterial pathogens which probably are transmitted vertically through the placenta from mother to progeny. Moreover, such bacteria have been described to be present in the erythrocytes causing their destruction through oxidation of hemoglobin with formation of hemosiderin (BISSET \& BARTLETT 1978; TEDESCHI et al. 1978; TEDESCHI \& DI IORIO 1979). Work is now in progress in the authors' laboratory on the identification of vertically transmitted pathogens in the B10.PL, the B10.PLderived knockouts, and the BALB/c mice. In the immunity-handicapped animals these endogenous microorganisms probably become active causing meningitis, blood clots with hemosiderin deposits inside and in the walls of blood vessels. The vessels thus become fragile and this may be the cause of the hemorrhages. The presence of a normal bacterial flora is indispensable for the development of immunity (JIANG et al. 2004) and the development of neuropathology in our animals is therefore probably caused by the lack of such flora and impaired immunity of the animals studied.

The hydrocephalus in the studied animals, except in the $\mathrm{CD} 1^{-/}$mice, was accompanied by involution of the pineal gland. The pineal gland indirectly stimulates immunity (MAESTRONI et al. 1987; MAESTRONI et al. 1989; PAWLIKOWSKI \& KARASEK 1990; MAESTRONI 1993) and pinealectomy or other experimental methods which inhibit melatonin synthesis induce a state of immunodepression. In general, melatonin seems to have an indirect immunoenhancing effect particularly apparent in an immunodepressive state (MAESTRONI 1993). The strong hypertrophy of the pineal in our $\mathrm{CD}^{1 /-}$ mice may be compensatory in response to the impaired immunity in these animals. 
The present results should be taken into serious consideration by all planning immunobiological studies not only on the B10.PL and B10.PLderived strains but also on other strains not studied for their possibly neuropathology. Animals with such severe changes in their brains are suspect to have aberrant regulation and control of immunologic processes by the central nervous system.

\section{Acknowledgements}

We thank Dr. M. SZCZEPANIK for the knockout mice, Dr. K. DZIOBEK for photographic documentation and L. KSIĄŻEK for expert technical assistance.

\section{References}

BISSET K. A., BARTLETT R. 1978. The isolation and characters of L-forms and reversions of Bacillus licheniformis var. endoparasiticus (Benedek) associated with the erythrocytes of clinically normal persons. J. Med. Microbiol. 11: 335-349.

JiANG H. G., THURNHEER M. C., ZUERCHER A. W., BOIKO N V., BOS N. A., CEBRA J. J. 2004. Interactions of commensal gut microbes with subsets of B- and T-cells in the murine host. Vaccine 22: 805-811.

MACPHERSON A. J. S., LAMARRE A., MCCOY K., HARRIMAN G. R., OdERMATT B., DOUGAN G., HENGARTNER H., ZINK-
ERNAGEL R. M. 2001. IgA production without $\mu$ and $\delta$ chain expression in developing B cells. Nat. Immunol. 2: 625-631.

MAESTRONI G. J. M. 1993. The immunoneuroendocrine role of melatonin. J. Pineal Res. 14: 1-10.

Maestroni G. J. M., Conti A., Pierpaoli W. 1987. The pineal gland and the circadian, opiatergic, immunoregulatory role of melatonin. Ann. NY Acad. Sci. 496: 67-77.

Maestroni G. J. M., Conti A., Pierpaoli W. 1989. Melatonin stress and the immune system. Pineal Res. Rev. 7: 203-226.

PAul R., Koedel U., Pfister H. W. 2003. Using knockout mice to study experimental meningitis. Arch. Immunol. Ther. Exp. (Warszawa) 51: 315-326.

PAWLIKOWSKI M., KARASEK M. 1990. The pineal gland and experimentally-induced tumors. (In: Advances in Pineal Research., vol. 4. REITER R. J., LUKASZYK A. eds. John Libbey, London, Paris, Rome): 259-265.

PEARSE A. G. E. 1960. Histochemistry, Theoretical and Applied. Churchill, London.

SABElKo-Downes K. A., Gimenez M. T., SuVAnNAVEJH G. C., MILLER S. D., RUSSELL J. H. 2000. Genetic control of pathogenic mechanisms in autoimmune demyelinating disease. J. Neuroimmunol. 110: 168-176.

SundBerg J. P., WoOlCott B. L., CUNLIFEe-BeAmer T., BROWN K. S., BRONSON R. 1991. Spontaneous hydrocephalus in inbred strains of mice. The Jackson Laboratory Notes 445: $1-2$.

SZCZEPANIK M. AKAHIRA-AZUMA M, BRYNIARSKI K., TSUJI R. F., KAWIKOVA I., PTAK W., KIENER C., CAMPOS R. A., ASKENASE P. W. 2003. B-1 B cells mediate required early $\mathrm{T}$ cell recruitment to elicit protein-induced delayedtype hypersensitivity. J. Immunol. 171: 6225-6235

TEDESCHI G. G., Di IORIO E. E. 1979. Penetration and interaction with haemoglobin of Corynebacteria-like microorganisms into erythrocytes in vitro. Experientia 35: 330-331.

Tedeschi G. G., Sprovieri G., Del Prete P. 1978. Cocci and diphtheroids in blood cultures from patients in various pathological situations. Experientia 34: 596-597. 